\title{
Den kloge mand i ølglasset - og andre historier
}

De "kloge folk", der kan kurere alskens dårligdomme, giver deres patienter nogle overraskende oplevelser, som festner sig sterkt $i$ erindringen og skaber store fortallinger til videregivelse. Dermed kan de selv gøre os andre klogere på de kognitive mekanismers betydning for traditionsoverleveringer - $i$ livet og $i$ arkivet.

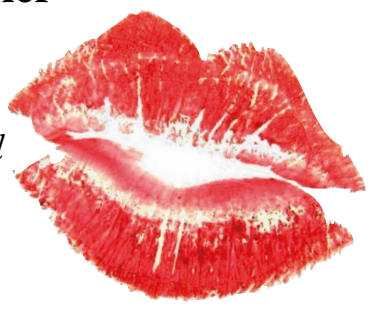
af projektforsker, ph.d. Kirstine Munk Dansk Folkemindesamling

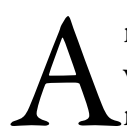
rtiklen her er et resultat af overvejelser, jeg har haft i forbindelse med et forskningsprojekt på Dansk Folkemindesamling om kloge folk før og nu. ${ }^{1}$ De kloge folk er mennesker, som uden formaliseret sundhedsfaglig uddannelse giver sig i kast med at kurere folk og fæ. Fænomenet er velkendt i historien, hvor de kloge ofte var den eneste mulighed for hjælp i forbindelse med ulykke og sygdom. De kloge kunne sætte en skulder på plads og kurere en bullen finger. De kunne afværge hekseri og lavede medicin af indsamlede urter, lakrids, brændevin og muselort og hvad de ellers mente kunne virke kurerende. ${ }^{2}$ Og så var mange af dem efter sigende tillige synske og beskæftigede sig med forskellige magiske praksisser. Disse sidstnævnte forestillinger i befolkningen gjorde, at mange var bange for de kloge folk, for de evner, man kan bruge til at gøre godt med, kan man også bruge til at forvolde ondt. ${ }^{3}$ Nogle af de kloge folk var meget kendte, flamboyante personligheder, mens andre levede en mere hengemt tilværelse som helt almindelige mennesker, der bare havde en eller anden specialviden om, hvordan man eksempelvis klarede forstuvninger eller hjalp pattegrise til verden. ${ }^{4}$ Dansk Folkemindesamlings bibliotek og arkiv indehol- der et stort materiale om disse - ofte indbyrdes meget forskellige - mennesker og deres kure.

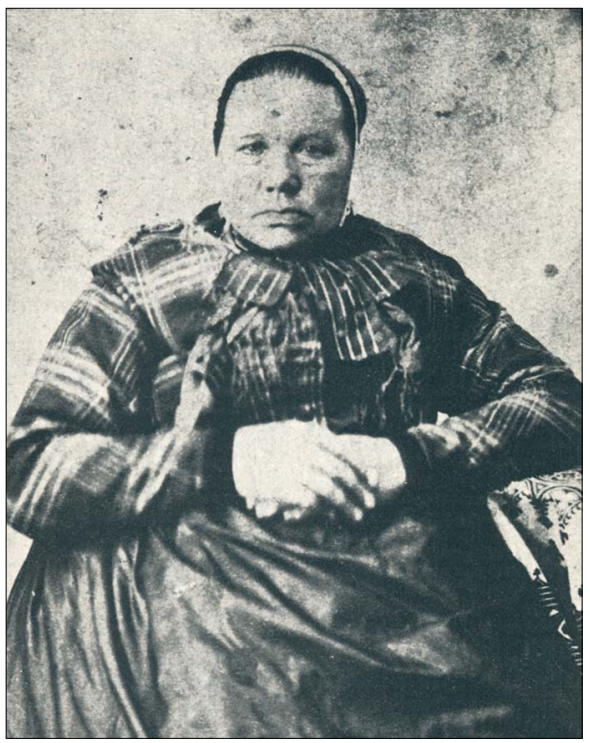

Anne Marie Jeppesdatter (1812-1884) var den kendteste kloge kone $i$ Tjørnehoveddynastiet - en familie på Prestø-egnen, der talte fire generationer af mere eller mindre kendte kloge folk. Ane Marie kurerede sine patienter med bade mediciner og magiske remedier, men det var den magiske del af hendes praksis, som fortellingerne om hende har haftet sig ved. (Gengivet efter Birgitte Rørbye: Kloge folk og skidtfolk. Kvaksalveriets epoke i Danmark, 1976). 


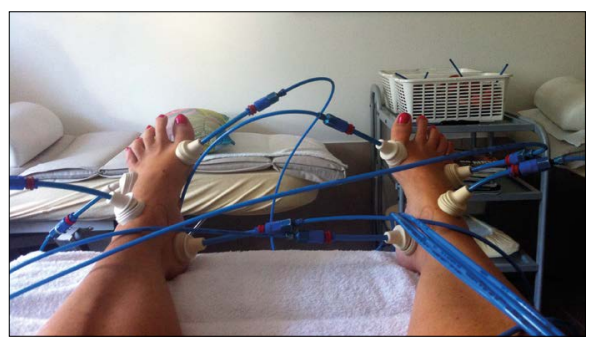

Hos Christian Andersen (f. 1942), som er tidligere automekaniker og en af de kendteste kloge folk i dagens Danmark, bliver man kureret ved hjalp af et vakuumsystem, han selv har udviklet (foto ved forfatteren).

Det har tidligere været antaget, at de kloge folks praksis ville blive overtaget af lægevidenskab og af den store alternative sektor, der er blusset frem siden 1960'erne. Dette har dog ikke været tilfældet. De kloge folk eksisterer endnu, men de annoncerer generelt ikke. Hvis man skal finde frem til de kloge folk, går det igennem mund-til-mund-metoden: Man har hørt om én, der kender én, der har været hos en klog mand eller kone og derfor kan fortælle den vildeste historie. De kloge folk fører sig ikke frem i offentligheden, og deres ry og praksis er derfor båret af alle de historier, som folk fortæller hinanden om denne eller hin kloge persons fantastiske evner. ${ }^{5}$

De kloge folk i vore dage er typisk mænd, som er lidt oppe i årene, og de har selv udviklet den teknik, de bruger, eller de er blevet lært op af deres far eller mor, som selv var klog. Der eksisterer således ved Fjerritslev i Nordjylland en familie af kloge folk, som går 8 generationer tilbage! ${ }^{6}$ De kloge folk er karakteriseret ved, at de ikke har en uddannelse, som er relevant i forhold til deres metier - de har typisk erhvervsbaggrund som f.eks. maskinarbejdere, automekanikere, fiskere, skovhug- gere, slagteriarbejdere eller andet teknisk eller manuelt, og deres tilgang til patienterne er meget håndværksmæssig. Deres sprog og deres gebærden med patienterne reflekterer dette: Som patient får man ikke særligt meget at vide. Man bliver bare "repareret". Af samme grund er der flere mænd, der kontakter kloge folk, end man ser indenfor det alternative område generelt. Som en klog mand sagde: "Vi er håndværkere, ikke forelæsere. Mænd vil ikke have alt muligt at vide. De vil bare fikses. Derfor kan de komme her"?

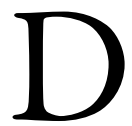
e lidelser, som de kloge folk har særlig succes med, er allergi, inflammatoriske lidelser (dvs. gigt m.v.), smertebehandling og problemer i bevægeapparatet. Patienterne kommer

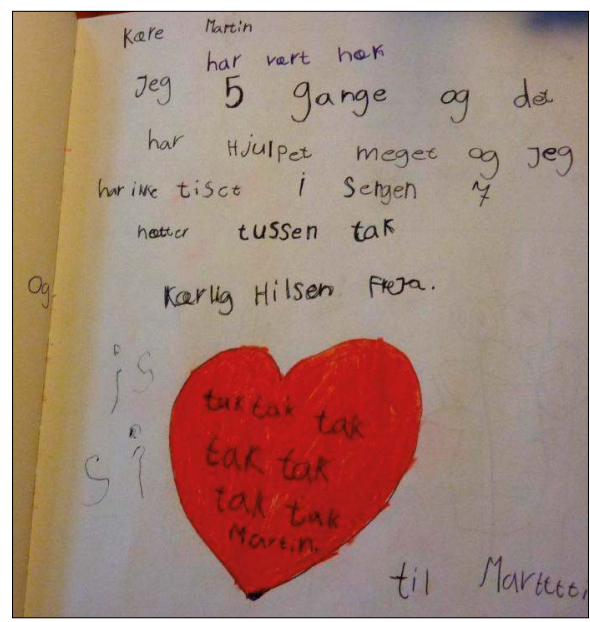

Hos den kloge mand Martin Haakonsen ved Ringkøbing Fjord ligger gastebøger fremme $i$ venteverelset, hvor patienterne kan skrive en hilsen. Disse gesteboger er fulde affantastiske beretninger og hilsner fra patienter. Her er alt fra sportsstjerner og kendte $T V$-folk til taknemmelige born, der efter endt behandling ikke langere tisser $i$ sengen om natten (foto ved forfatteren). 
bogstaveligt talt fra alle samfundslag. Der er alt fra balletdansere til fiskere, taxachauffører og direktører - fortællingerne findes $i$ alle lag af samfundet, men der er et forhold, der går igen: Jo vildere og jo mere overraskende en historie er, jo større chance har den for at cirkulere bredt.

\section{Hukommelse og fortælling}

"Fortællinger er kulturens mønt", 8 og det, man kommer hjem med som kulturforsker på feltarbejde er netop primært fortællinger. Vi videregiver oplevelser og erfaringer til andre i fortællingens form, men vi oplever og erfarer også vores livsverden i narrative skemaer. Det siger sig selv, at for at kunne fortælle om et hændelsesforløb til andre, er vi nødt til at kunne huske det selv. Men som den eksperimentelle kognitive forskning viser, er vores hjerne netop ikke bare en blank tavle, som alting kan nedfældes på, så det bliver stående. Der er simpelthen ting, man ikke kan huske, og andre oplevelser, som nødvendigvis må blive hængende - også selvom man prøver på at glemme dem.

Indenfor både antropologi og religionsforskning arbejder man blandt andet med at integrere den tværfaglige kognitive forskning i studiet af tradition. Ordet tradition kommer fra det latinske ord 'tradere, som betyder "at videregive", og traditioner har jo det fælles træk, at der er tale om viden og praksisser, som er blevet videregivet, og som derfor i en vis forstand gentages og bliver en del af den fælles kulturelle viden og praksis. Men for at denne gentagelse kan finde sted, skal det hele jo huskes, og her er pointen, at kulturel viden grundlæggende vil have to forskellige former for overførsel, som svarer til de to forskellige måder, hvorpå vi kan gemme information i hukommelsen.
Helt overordnet har vi to typer hukommelse: Den episodiske (eller selvbiografiske) og den semantiske.

Den episodiske hukommelse knytter sig til episoder i vores liv, som står ud i erindringen, fordi det er noget, vi oplever for første gang, eller fordi den ikke passer med vores forventninger om, hvordan tingene skal være. Den episodiske hukommelse indsamler således primært oplevelser, som er overraskende eller forstyrrende, og som har en stærk følelsesmæssig eller sanselig kvalitet: De fleste husker sikkert deres første kys - men hvem husker kys nr. 27?

Kys nr. 27 indlejres derimod i den semantiske bukommelse som en generaliseret viden i vores såkaldte mentale skema for, hvordan det er at kysse. Vi har myriader af sådanne skemaer indlejret i vores semantiske hukommelse, og derved kan vi let navigere i verden: Vi ved hvordan man parkerer en bil, går til lægen og køber ind i Brugsen - uden at skulle tænke over hvert enkelt trin i processen. Den semantiske hukommelse indlejrer tillige vores generaliserede viden på den måde, at vi ikke husker præcist, hvordan vi erhvervede den. Vi husker eksempelvis, at ingefær hedder "ginger" på engelsk, men vi husker ikke hver enkelt af de talløse gange, vi slog ordet op. At slå ord op i en ordbog er ikke en begivenhed, der har det, der skal til, for at blive hængende som en unik episode i vores erindring.

Den semantiske hukommelse indlejrer ved hjælp af gentagelser. Her ligger både kasserollebøjningen og vores "fader vor". Hvis en information eller hændelse ikke er sanseligt rig, overvældende, overraskende eller har stor personlig og følelsesmæssig prægnans, så skal den gentages mange gange før den sætter sig rigtigt på plads i 


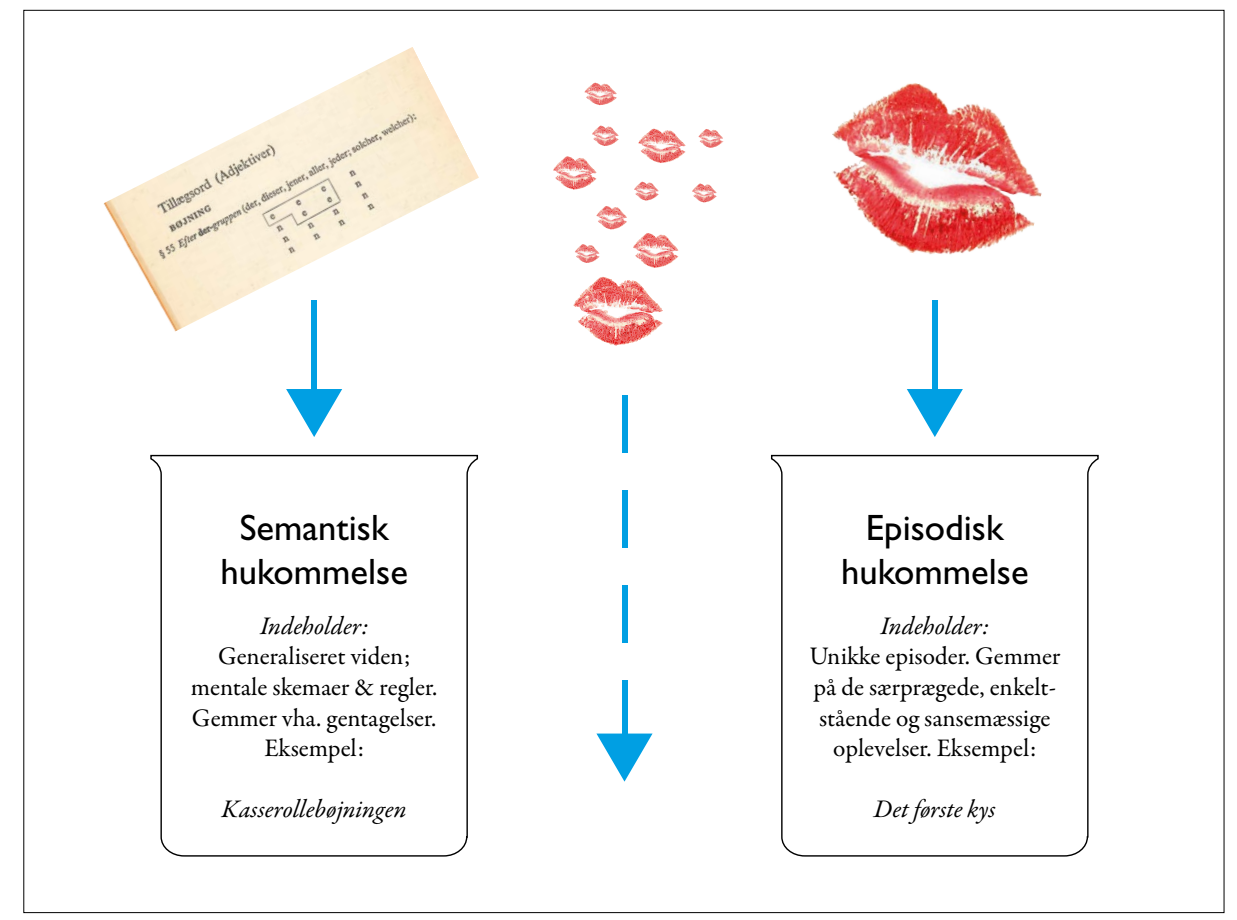

Figuren viser, hvorfor nogle begivenheder ikke kan huskes som enkeltstaiende oplevelser. Kys nr. 27 har ikke det, der skal til, for at det kan gemmes i den episodiske hukommelse. Man husker det kun kortvarigt, men over tid bliver det i stedet en del af skemaet for at kysse. Vi vil ikke kunne fortelle andre om vores 27 . kys.

den semantiske hukommelse. Hvis vi kun hører kasserollebøjningen en enkelt gang og aldrig læser på lektien siden, så husker vi den ikke, for den vækker ikke vores sanser og følelser i en sådan grad, at den kan indlejres i den episodiske hukommelse. $\mathrm{Og}$ hvis den ikke gentages, indlejres den heller ikke i den semantiske.

S om med hukommelse taler men også om, at der er to typer traditioner: ${ }^{10}$ Den dogmatiske, som hviler på skriftlighed, gentagelse og entydighed, og som primært indlejres i de enkelte kulturbæreres semantiske hukommelse, og den imagistiske, som indlejres i den episodiske hukommelse, og som lægger vægt på flertydighed, sanselighed, erindringsbilleder, overraskelser og kreative udviklinger snarere end på regelret gentagelse og logisk integration. ${ }^{11}$ Derfor kan man se store lokale forskelle, når den imagistiske tradition har fortrinsret, hvorimod det kun er de skriftbårne (og dermed dogmatiske) traditioner - så som protestantisk kristendom eller vestlig videnskab - der har mulighed for opnå større udbredelse.

\section{De kloge folks imagistiske praksis} De kloge folk har primært en sansebåret praksis. I tidligere tider har de af og til konsulteret lægebøger, men i det histo- 
riske materiale er der især lagt vægt på de kloge folks såkaldte cyprianusser, som var primært selvlavede bøger med diverse medicinopskrifter og magiske formler. Det er dog påfaldende, at der verserede så meget folketro omkring disse bøger: F.eks. kunne man ikke dø, så længe man havde en cyprianus, og den var farlig at kigge i for udenforstående osv. Men når man læser disse cyprianusser og beretningerne om de kloge folk bliver det klart, at cyprianussen primært var et imagistisk remedie, som skulle vække følelser, inspiration og stemninger, snarere end en manual, man fulgte til alle tider. Således kunne den samme kloge mand behandle to ens tilfælde helt forskelligt, hvilket tyder på, at han ikke konsulterede en bog. Og desuden var der gennemgående ret få opskrifter i en cyprianus i forhold til den mængde af lidelser, som de kloge folk efter sigende kurerede. ${ }^{12}$

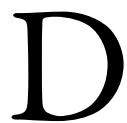
e kloge folk i vore dage er ligeledes mennesker, som har et meget "løst" forhold til den eksisterende tradition og sundhedsfaglige viden, og som oftest har de selv opfundet deres primære helbredelsesmetode. De er af samme grund en meget uensartet flok. De har prøvet sig frem, og alle overraskelserne og succeshistorierne har indlejret sig i deres episodiske hukommelse. De læser, men det er primært diverse åbenbaringer af både auditiv, kinetisk og visuel art, som har ført dem frem til den arbejdsmetode, de bruger. Når de fortæller om noget, som de har læst et sted, kan de aldrig huske, hvor det kommer fra. Men de husker menneskelige møder, følelserne, overraskelserne, kropsfornemmelserne og åbenbaringerne. Således er der en stor grad af uensartethed over traditionen.

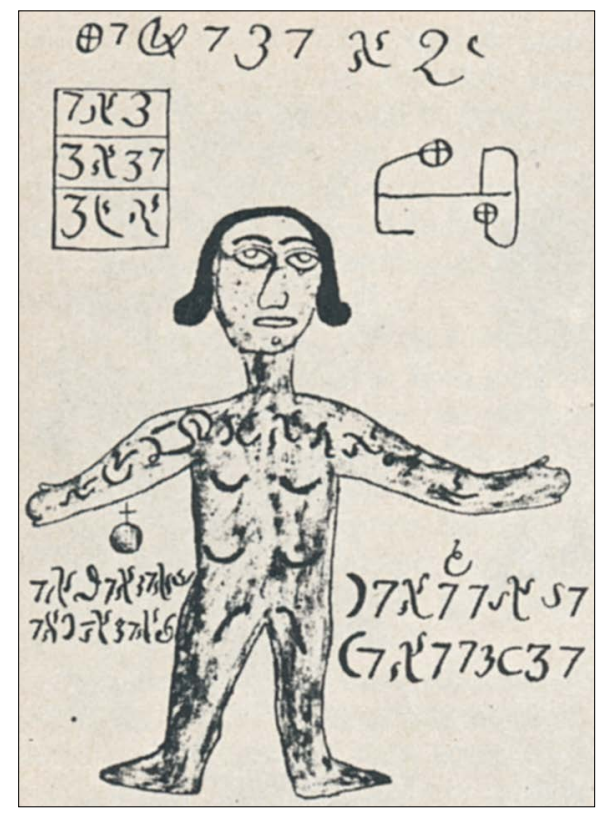

Tidligere var de kloge folks vigtigste händbog en cyprianus, hvori diverse medicinske opskrifter og magiske formularer var nedskrevet. Bogerne var forbundet med en stor grad af arefrygt og måtte ikke lases af udenforstaiende (Gengivet efter Birgitte Rorbye: Kloge folk og skidtfolk. Kvaksalveriets epoke i Danmark, 1976).

Den indlejres primært i den episodiske hukommelse.

Når vi oplever noget nyt, vil vores hjerne forsøge at finde et eksisterende skema for det, og når det ikke lykkes, vil den alligevel prøve at finde noget, som den kan hænge episoden op på og give den mening. ${ }^{13}$ Et første besøg hos en klog mand i vore dage kan i nogen grad anvende eksisterende skemaer, eksempelvis for "sådan kommer man ind ad døren" og man bruger måske dele af sine skemaer for "sådan går man til læge", eller "sådan går man til kiropraktor", men før eller siden bliver skemaet brudt, netop fordi de kloge 
folks praksis er så forskellig fra, hvad man ellers har været udsat for.

Når nutidens mennesker går til kloge folk første gang, sker det som regel ud fra ren og skær desperation. Patienterne har forinden prøvet alt, der er at gøre indenfor det etablerede system, og nu har de hørt om en klog mand eller kone, der nærmest har kunnet udvirke mirakler, så nu prøver de det - selvom de faktisk ikke tror på det!

Et besøg hos en klog mand eller kone sætter en masse kognitive processer $i$ gang: Forestil dig at blive helbredt for en diskusprolaps af en aldrende automekaniker, der behandler dig, som om du var en gammel bil og sætter en masse slanger med sugekopper på dig, som er forbundet til en generator ude i baghaven! Eller at blive "ordnet" for allergi ved at ligge og blive trykket udenpå tøjet på en briks i dagligstuen hos en klog mand, mens alle de andre patienter sidder i sofaarrangementet lige ved siden af og kvidrer, mens de venter på at det bliver deres tur. $\mathrm{Og}$ forestil dig så at det virker! Efter måneders ellers års trængsler med din lidelse!

lle fortællingers brændstof er det
overraskende, det problemfyldte,
det voldsomme eller det, der på en eller anden måde "står ud" fra skemaerne. ${ }^{14}$ Efter at have oplevet en succesfuld kur vil patienter ofte komme igen med alle mulige mindre skavanker, som opstår i tidens løb, og den kloge vil ikke længere være den sidste mulighed. Men disse helbredelser af småskavanker huskes ikke nær så godt. ${ }^{15}$ Alle disse enkeltstånde episoder ryger efterhånden ned i den semantiske hukommelse og bliver til et skema for "sådan er det at gå til klog mand". Jo mere syg, man har været, jo mere mærkelig

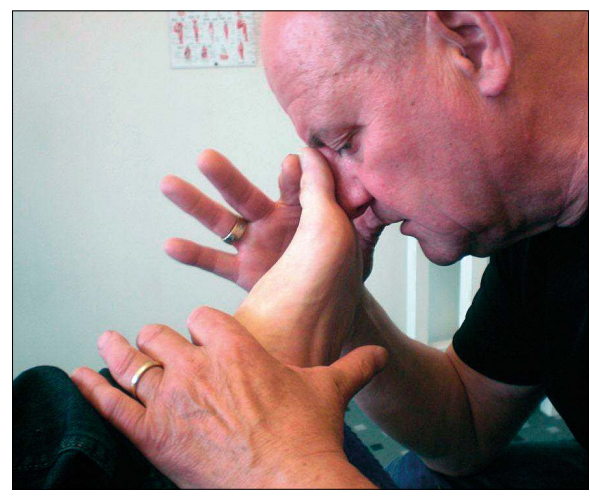

Per Gjeding i Odense er tidligere bager og slagter. Efter et alvorligt uheld med ryggen, hvor han var lammet fra baltestedet og nedefter, trenede han sig selv op, efter at hans storetå en dag tilfaldigt var kommet til at ramme sengegardet. Aktiveringen afstoretaien er en central del af behandlingen, som aldrig fraviges. Man ligger ned på en briks, mens Pers ansigt er nede ved ens fodder, og så skal man trykke ham flere gange hårdt pà nesen med sin tå. Det virker hojst besynderligt, når man ligger midt i det, men fra fotos, avisudklip og takkekort i forhallen, kan man konkludere, at man ikke er alene om denne oplevelse. Alle mulige mennesker - lige fra prins Henrik til haindboldpigerne og kendte popstjerner har ligget og trykket mod den kloge mands nase, og ud fra takkekortene at domme har det tilsyneladende hjulpet dem godt!

kuren er, og jo mere håbløst ens tilfælde var, jo større chance er der for at historien fortælles videre - også af andre.

\section{Materialeindsamling og formidling}

De kognitive mekanismer vedrørende fortælling og hukommelse er ligeledes $i$ spil for en forsker på feltarbejde, og de bestemmer ligeledes, hvilke typer fortællinger, der er at finde i arkiverne. Når man kigger i Dansk Folkemindesamlings arkiv efter indsamlet materiale om kloge 
folk, er der en ting, der virker meget besynderlig: Når man nu ved, at de kloge folk tidligere var den primære hjælp at få i forbindelse med alskens sygdomme, hvorfor er der så stort set ingen fortællinger om det? Småskavankerne nævnes stort set ikke. Uprægnante foreteelser, så som at gå til klog mand med en bullen finger, står ikke ud med nogen særlig detaljeringsgrad i fortællingen, så man kan læse sig til hvorfor og hvordan. Derimod er der i arkivet rigtig mange fortællinger om den flamboyante kloge mand, lommetyv og lurendrejer Laust Glavind (1808-1891), der en gang på en markedsplads tilsyneladende lavede det nummer, at han tryllede sig selv ned i et ølglas! $!^{16}$ Numerisk set fylder denne episode forholdsvis meget i arkivnumrene. Det samme gør fortællinger om den kloge kone Maren Haaning (1782-1853), der kunne trylle folk sorte af lus, når hun ikke kunne lide dem, og som i øvrigt drak, bandede og svovlede, men havde klienter fra nær og fjern, som hun tilsyneladende hjalp godt. ${ }^{17}$ Det er ligeledes netop de kloge folk, der tydeligst bryder normer og forventninger, som har været genstand for beskrivelse i monografier om tidligere tiders kloge folk. ${ }^{18}$ Men dermed kommer man som moderne læser let til at tro, at netop disse kloge folk, som er mest indgående beskrevet, er de mest tidstypiske. Mit argument er, at det sikkert ingenlunde har været sådan.

I bøger om de kloge folk står der ofte i beskrivelserne om dem, at de var drikfældige, usoignerede og talte grimt. Ved nærlæsning ser man, at det, der kommer med i beskrivelsen, ofte er handlinger og karakteristika, der bryder de gældende normer. Man kan nemt få det indtryk, at de kloge folk generelt var socialt akavede:

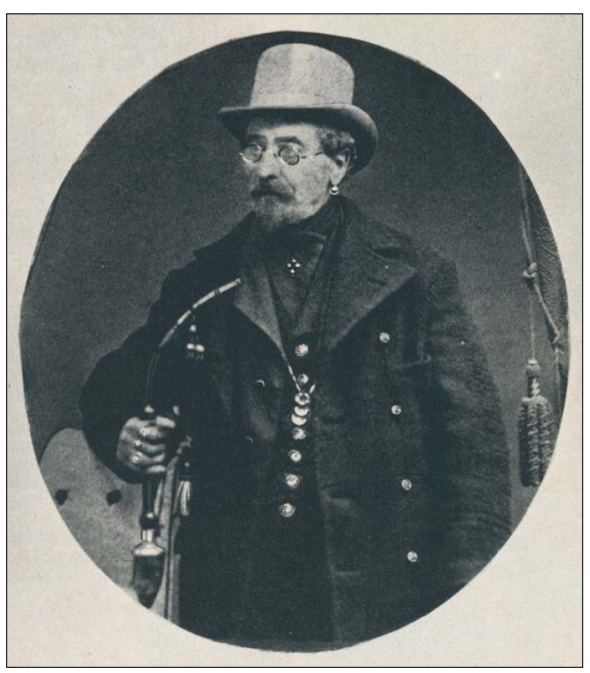

Laust Glavind (1808-1891). Hans prangende påkladning med de mange smykker samt hans blakkede fortid og mangeartede evner har fäet ham til at stå ud fra mangden, således at han i dag er en af de mest velbeskrevne af datidens kloge folk. Der er desvarre ikke noget billede af ham i olglasset! (Gengivet efter Birgitte Rorbye: Kloge folk og skidtfolk. Kvaksalveriets epoke i Danmark, 1976).

De blev hængende alt for længe, når de var på besøg, drak folk ud af huset, havde en lidt for ligefrem sprogbrug, tørrede snot af $\mathrm{i}$ buksebenet og var grimme som bare fanden. Men det er langt fra hele billedet. Disse beskrivelser fylder bare mere, både i fremstillingerne og i læserens hoved, fordi vores hjerner giver mere opmærksomhed til det, der bryder forventningen. ${ }^{19}$

Overarkivar Else Marie Kofoed har bemærket, hvordan menneskers fortællinger om deres konfirmation, især i det ældre materiale, eksempelvis ofte kan være negative. En konfirmation er ideelt set en glædelig hændelse, men det, der huskes, er, hvordan man skulle stå i kirken i det stiveste puds - og så stod man dér 
i nogle gamle træsko, fordi der ikke var råd til andet. Lige netop dette element træder frem, fordi en konfirmation er en begivenhed, der følger et fast skema. Man har været med til andres konfirmationer og man ved, hvordan en konfirmation ret skal være. Samtidig er ens egen konfirmation en enkeltstående begivenhed, der indlejrer sig i den episodiske hukommelse som en del af ens personlige livsfortælling. Den episodiske hukommelse samler, som tidligere nævnt, oplevelser af stærk følelsesmæssig og personlig relevans, og den gemmer det, som er enkeltstående eller "forstyrrende". Man husker personlige højdepunkter og lavpunkter. Derfor husker man ikke, hvad præsten prædikede eller hvilke sange, der blev sunget $i$ kirken den dag - de er bare indlejret som en del af skemaet for at gå i kirke - men man husker det tøj, man havde på. Konfirmationen er en både individuel og social begivenhed, der iscenesætter identitet og status i gruppen. Og derfor er det indsamlede materiale så fyldt af beretninger om skuffende og krænkende konfirmationer. Alt det, der følger skemaet, vil simpelthen ikke få den samme prægnans. Samtidigt er det rimeligt at antage, at de mindre frapperende konfirmationsoplevelser også har været der - selvom de nødvendigvis

\section{Noter}

1 Projektet, der blev støttet af Kulturministeriets forskningspulje, fandt sted fra november 2011 til juni 2013. Det involverede gennemgang af ældre kilder i forhold til studiet af sammenhæng, brud og kontinuitet, samt feltarbejde, analyse og indsamling af materiale om nutidens kloge folk og deres klienter i hele landet.

2 Der findes mange cyprianusser med de kloge folks opskrifter i. Det letteste sted må komme til at fylde mindre i materialeindsamlingen.

Jeg har selv bemærket, hvordan jeg, når jeg har holdt foredrag om de kloge folk, eller når jeg skriver artikler om dem, uvægerligt kommer til at vælge de eksempler, som netop er de mest overraskende. Det er simpelthen de bedste historier. Jeg elsker at fortælle folk om den tidligere automekaniker fra Amager, der nu er blevet hoflæge for det saudiske kongehus, eller om den kloge kone fra Djursland, der diagnosticerer sine patienters lidelser ret præcist ved hjælp af åndelig kontakt med en afdød Shetlandspony! På samme måde fylder lidelser som myoser og hold i ryggen rigtig meget i de kloge folks praksis, men den type historier flyder lidt sammen for mig $i$ erindringen, og ingen læser ville alligevel gide høre om dem alle sammen! Men man vil rigtig gerne høre om den unge mand, der blev lam efter et trafikuheld og på mirakuløs vis blev bragt tilbage til førligheden af en klog mand! Således påvirker de kognitive mekanismer, der styrer hukommelse og fortælling, ikke bare hvilke historier, vi får samlet ind under feltarbejdet. De bestemmer i høj grad også hvilken del af materialet, der står ud i vores egen erindring, og hvad vi selv primært bringer videre.

at starte for et generelt indblik i de kloge folks praksisser er H.P. Hansen: Kloge folk. Folkemedicin og overtro i Vestjylland, I-II, 1960-1961. Heri er blandt andet Henrik Kokborgs cyprianus trykt, hvorfra disse eksempler er taget (bind 1 s. 41-71).

3 Se eksempelvis Evald Tang Kristensen: Danske Sagn som de har lydt i Folkemunde. 6. Afd., anden halvdel, 1901, samt $\mathrm{Ny}$ Række, 6. Afd., 1936. 
4 Se eksempelvis Birgitte Rørbye: Kloge folk og skidtfolk. Kvaksalveriets epoke i Danmark, 1976.

5 De særlige fortællinger, der knytter sig til de kloge folks omdømme og praksis, kan man læse mere om i forfatterens artikel: "And Then It Was Fixed: The Storytelling that Surround Cunning Folks". Bulletin for the Study of Religion (under udgivelse).

6 Tabita Wulff: Bratbjergmandens datter. En nordenfjords naturlege-slegt og deres hemmelige opskrifter, 1996.

7 Forfatterens feltarbejde 2013.

8 Jeg skylder Jerome Bruner denne formulering. Og han forklarer: "For culture is, figuratively, the maker and enforcer of what is expected, but it also, paradoxically, compiles, even slyly treassures, transgressions. Its myths and its folktales, its dramas and its pageants memorialize both its norms and notable violations of them." (Making Stories. Law, Literature, Life, 2002, s. 15)

9 Fremstillingen her er forenklet. Ikke alt, der indlejres i den episodiske hukommelse, er selvbiografisk, men al selvbiografisk hukommelse er episodisk for så vidt, at det drejer sig om episoder, der gemmes i vores selv-fortællinger. En tur i skoven kan vi huske i en begrænset tid frem, men dén tur i skoven, hvor vi mødte vores livs kærlighed for første gang, indlejres som en del af vores selvbiografiske erindring og holder længe. Se eksempelvis Charles P. Thompson et al.: Autobiographical Memory: Remembering What and Remembering When, 1996. Alle de andre almindelige gåture er episoder, der bliver del af skemaet for at gå tur. Således kan man sige, at semantisk viden er "abstraheret” fra episodiske erindringer; G. Cohen: Memory in the Real World, 1989.

10 Det er antropologen Harvey Whitehouse, der indledte denne type forskning i religiøs transmission og hukommelse, som siden har fået vind i sejlene. Se
Harvey Whitehouse: Arguments and Icons. Divergent modes of religiosity, 2000. Harvey Whitehouse: Modes of Religiosity. A Cognitive Theory of Religious Transmission, 2004. Harvey Whitehouse \& Robert N. McCauley (red.): Mind and Religion: Psychological and Cognitive Foundations of Religiosity, 2005. Pascal Boyer \& James V. Wertsch (red.): Memory in Mind and Culture, 2009.

11 Dette minder lidt om Jerome Bruners to tankemåder, henholdsvis den paradigmatiske og den narrative (eller "konjunktiviske”). Hvor førstnævnte drejer sig om at tænke i systemer, søger entydighed og benytter en høj grad af abstraktion, så beskæftiger den narrative tænkning sig med muligheder, enkeltheder, og åbner sig for stadig fortolkning (Actual Minds, Possible Worlds, 1996).

12 Se f.eks. H.P. Hansen: Kloge Folk. Folkemedicin og overtro i Vestjylland, II, 1961, s. 6-67.

13 Se f.eks. Roger Schank: Tell Me a Story. A New Look at Real and Artificial Memory, 1990.

14 Se f.eks. Jerome Bruner: Actual Minds, Possible Worlds, 1986.

15 Det er indlysende, at hvis en behandling hos en klog ikke har virket, så huskes begivenheden heller ikke særlig godt, netop fordi det ikke virker særligt overraskende for den typiske moderne klient.

16 Arkivsignatur DAFO-klog 2403.

17 Arkivsignatur DAFO-klog 1606.

18 Eksempelvis Louise Rasmussen: De kloge koner $i$ Vindbles. Maren Haaning, 1927. Johannes Bech: Laust Glavind. Vestjyllands sidste troldmand, 1939. Henry Bailum: Laust Glavinds bedrifter, 1968-69.

19 Ligeledes kan jeg heller ikke undgå at bemærke det, når jeg kommer ud til en klog mand eller kone, der er storryger. I vore dage falder rygning helt klart udenfor, hvad man forventer hos en behandler, der arbejder indenfor det alternative område. 